\title{
Men in nursing: The early years
}

\author{
Martin Christensen * \\ School of Nursing, Queensland University of Technology, Caboolture Campus, Queensland, Australia
}

Received: October 7, 2016

DOI: $10.5430 /$ jnep.v7n5p94
Accepted: November 3, $2016 \quad$ Online Published: January 3, 2017

URL: http://dx.doi.org/10.5430/jnep.v7n5p94

\begin{abstract}
Objective: Nursing is as old as mankind and the nature of what it means to be a man in nursing has a wide and varied history. Men have been at the forefront of nursing practice from before the birth of Christ - the first record of male nursing originates from ancient India. Slowly over time the image of the male nurse has given way to the dominance of women largely thanks to Florence Nightingale. The aim of this paper is to discuss the contribution men have made to the profession of nursing through the early years of nursing's history in particular from 250BC to the early 1900's.

Methods and result: Design: A historical review. Data Sources: The search strategy included research studies both qualitatively and quantitatively, as well as anecdotal and discursive evidence from 1900-2015. Implications for Nursing: The predominance of the history of has always had a focus on the female perspective. Men have had played a significant part in the development of that history. Acknowledging the role men have contributed in developing and promoting nursing practice is equally as valid and as such should be recognised accordingly.

Conclusions: Male nursing has had a varied history from the first recoded nursing school in $256 \mathrm{BC}$ to its slow eventual slow demise from the 1840's. Records reveal the work of the male nurse was seen predominately within secular institutions and personified aspects of care that focused totally on patient wellbeing both physically and spiritually.
\end{abstract}

Key Words: Men in nursing, Male nurse, Male nursing men as nurses

\section{INTRODUCTION}

The history of the male nurse has often been viewed along with nursing synonymously. Indeed one only has to look at the history of nursing to see the influential individuals who have shaped nursing -today - Florence Nightingale, May Seacole, Edith Cavell, Ethel Gordon Fenwick, and of course Ellen Doughtery the first registered nurse, to name a few. Of course probably the most prominent male nurses would be $\mathrm{St}$ Benedict, St Alexis, St Camillus, Walt Whitman and Luther Christman. Despite the rhetoric of nursing being the female dominion, male nurses have been in existence for over 2,000 years and while nursing historians would be the first to agree that men were present it is often forgotten, though not in- tentionally, that men have lead the development of nursing practice. Authors like Evans (2004), ${ }^{[1]}$ O'Lynn (2007), ${ }^{[2]}$ Bullough and Bullough (1993) $)^{[3]}$ and Mackintosh (1997) $)^{[4]}$ have gone some way in illuminating the work of the male nurse over time. However, it is only in the last 166 years that nursing has become predominately female in the provision of care and this was largely as a result of the sterling work of Florence Nightingale. But it must be remembered that the patron saint of nursing is a man.

\section{BACKGROUND}

Nursing is as old as mankind. The term nurse can be found in ancient Latin text as nutricius (5th century), middle English

\footnotetext{
*Correspondence: Martin Christensen; Email: martin.christensen@qut.edu.au; Address: School of Nursing, Queensland University of Technology, Caboolture Campus, Queensland 4510, Australia.
} 
as nurice (13th century) and in old French as nourice (18th century) all meaning "to nourish or nourishing". Contrary to contemporary opinion, men have been at the forefront of what we now call nursing care from before the time of Christ. It is only in the last 166 years that women have become the dominate figures within nursing, so much so that they make up nearly $90 \%$ of the current global nursing workforce. However, there is very little information which identifies with any certainty what constituted nursing practice prior to 1850 . Indeed, the literature concerning ancient medical/nursing care appears to have been consumed by medicine. The work of ancient healers in particular gives testament to the level of what we would now refer to as modern nursing care and practice that was being administered during this time, and while 'medicine' may have been performed what constituted medicine in ancient times was considered little more than magic undertaken by the religious few. ${ }^{[5]}$ There is clearly evidence within the literature of research and discussion loosely related to the history of men in nursing which offers some discussion of male nursing's history from its early recorded beginnings in 250BC up until the modern era. However, within this paper a closer examination of the varied and often violent history of male nursing will include the development of hospital nursing in 300AD during the Byzantium period, the Middle Ages, the Crusades of the 12th and 13th centuries, the Reformation and the Renaissance.

\section{SEARCH STRATEGIES}

A search of CINAHL, PubMed and Medline for research studies included qualitative and quantitative, as well as anecdotal and discursive evidence from 1900-2015. Only published studies in English were considered. Of the 3,351 abstracts reviewed 3,184 were withdrawn due to duplication and being overly generic in their approach to be of any relevance and therefore these articles were considered outside the remit of this paper (see Figure 1).
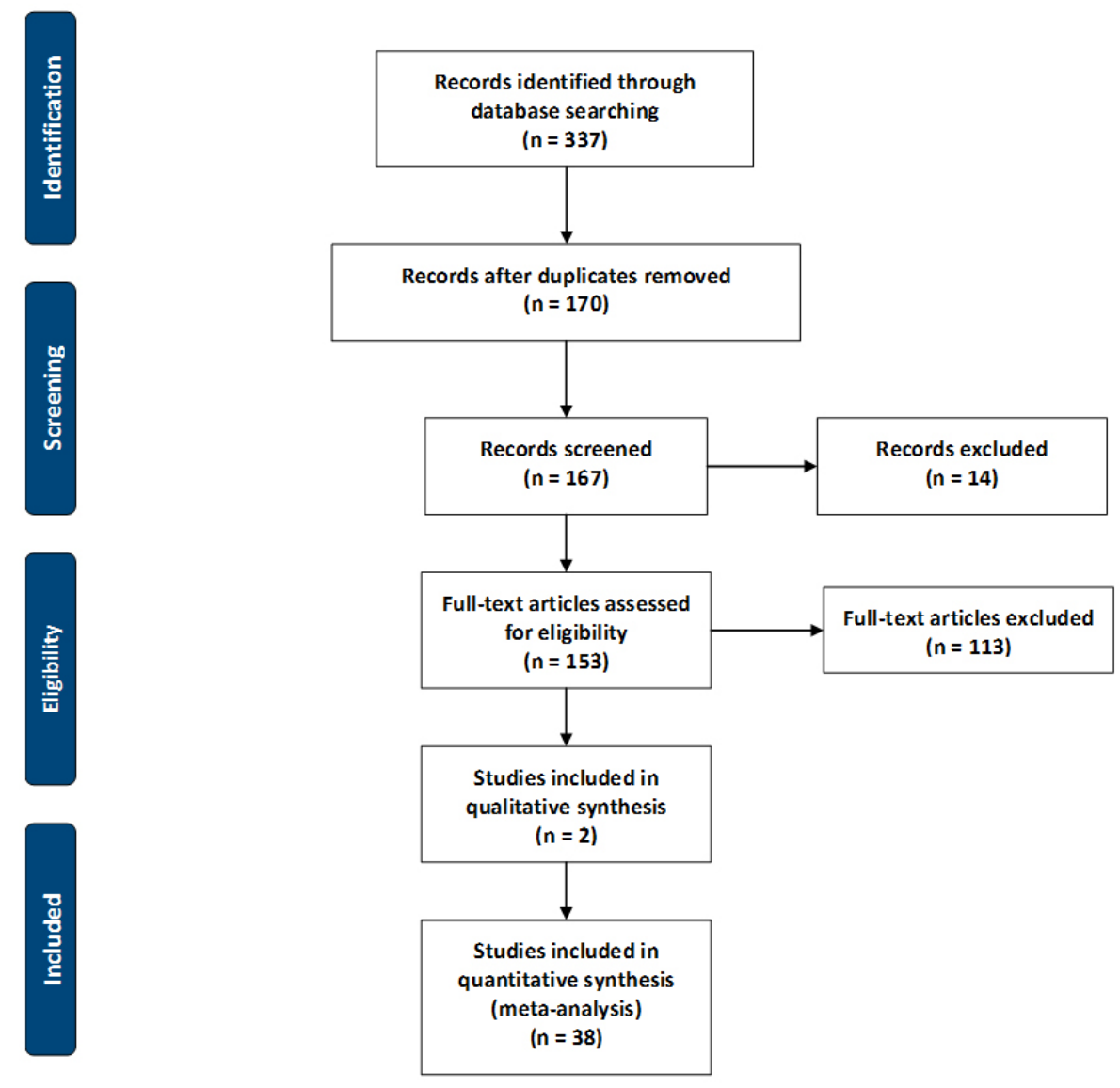

Figure 1. PRISMA diagram of article search

The search elicited a number of historical constructs that

Ages and the Reformation.

allowed for the history of male nursing to be more contextu-

ally aligned: Ancient Nursing; the Christian era; The Middle 


\section{ANCIENT NURSING AND THE PRE- CHRISTIAN ERA}

The earliest recorded details of the male nurse comes from India in 250BC with the opening of the first school of nursing predominately for men - females were seen as impure. ${ }^{[2,6]}$ The description of the nurse according to the Sutrasthanam $(1916 ; 307)$ in the 4th century BC, suggested the 'man' to be:

“...that person alone who is fit to nurse or to attend the bedside of a patient, whom is coolheaded and pleasant in his demeanour, does not speak ill of any body, is strong and attentive to the requirements of the sick, and strictly and indefatigably follows the instructions of the physician"

In addition to the virtues and the intrinsic qualities that the nurse was considered to possess, when it came to the application of nursing knowledge and skills it was evident that the nurse should be:

“... endued with kindness, skilled in every kind of service that a patient may require, endued with general cleverness, competent to cook food and curries, clever in bathing or washing a patient, well conversant in pressing the limbs, or raising the patient or assisting him in walking or moving about, well-skilled in making or cleaning beds, competent to pound drugs, or ready, patient, and skilful in waiting upon one that is ailing, and never unwilling to do an act that they may be commanded to do." (Nutting \& Dock, $1937 ; 34)^{[7]}$

The status of ancient Indian nursing as well as medicine far exceeded that of the west, so much so that streets and roads near hospitals were lined specifically with trees that had medicinal properties. ${ }^{[8]}$ Due in part to the work of Buddha in preaching the spirit of compassion to others, the development of scientific medicine grew espousing the benefits to humanity. However there are distinct texts that refer specifically to nursing practice and care during this time. For example, it was the Charaka and Susruta, 4th century BC Indian medical (healer) texts, that nursing came to be recognised for what it was-an art defined by the 'tetrad desiderata' [sic] as possessing skilled knowledge, cleanliness and affection for the patient. ${ }^{[5]}$

While these ancient 4th century BC Indian texts provide some early insight and affirmation to the role of the nurse and especially that of the male nurse, it must be remembered that the practice of 'medicine', or healing as it should be ideally referred to, and nursing was in existence in ancient Egypt long before. Indeed, it was during these ancient times, especially in the Greco-Egyptian period, that the preponderance of male nurses was possibly at its highest. For example, the virtues of manliness of which espoused aggression and masculinity exemplified the omnipotence of men; this resulted in the working classes comprised solely of men-women were forbidden to seek paid work outside the home environment. This led to the dominate belief of the time that healing and healers (paid employment) were by and large associated with sacredness and as such embodied the gods. The most powerful reigning gods of the time were male which intrinsically meant only men could be nurses or in this case healers. The celebrated Ebers (1550BC) and Edwin Smith (1600BC) papyri for example, described as the ancient encyclopaedias of medicine and have been dated as far back as $4688 \mathrm{BC}$, describe specific disease processes and their requisite treatment. ${ }^{[9]}$ Medical historians have been quick to attest that techniques mentioned in the papyri as those considered to be the domain of the physician. ${ }^{[10]}$ Techniques such as manipulating, bandaging and suturing were seen as part of the wider role of the doctor. Yet, Rosalie $(2008)^{[11]}$ has been quick to point out that there are significant problems with interpreting and translating words and terms found in the papyri and as such the contents of the papyri remain speculative at best. Of course the practice of 'medicine' as it has been described here could have easily been attributed to the care delivered by nurses if one is to put this into a modern context. For example, Caton (1879) ${ }^{[12]}$ writes of the priests at Herion prescribing massage, simple dietetics, the application of poultices and the administration of pain relieving medicines. While it is probable that nurses were present during this time it is difficult with any certainty to describe their duties and functions because of the overlap with the work of other 'health care professionals' of the time. However, it is known that these persons were invariably men and holy men at that. ${ }^{[7]}$

The continued evolution of nursing care through the preChristian era was seen foremost during the 'Greco-Roman' period. It is widely accepted among the medical fraternity that Hippocrates was the founding father of medicine and he set the precedent to ethical medical practice. ${ }^{[13]}$ However, there is evidence to suggest that Hippocrates was probably the first to recognise the role of the nurse (Hyperetai) in supporting the work of the 'healer'. ${ }^{[14]}$ In the Hippocratic Corpus (Decorum), for example there is reference to the work of the 'Hyperetai' in relation to the instructions left by the presiding physician: 
"Let one of your students [or nurses] be placed in charge to apply your instruction, not rigidly, yet to administer the treatment as ordered. Select from this group those already initiated in the art, to supply what is needed or to give treatment safely... state in advance all of this for the benefit of those who are to do the work and for whom the added information is necessary." (Levine \& Levine, 1965; 87) ${ }^{[14]}$

It is possible that Hippocrates identified the key role assistants would make in supporting the patient through their illness trajectory. Galen himself in his writings refers to the servile professional assistant (the male nurse) in the performance of tasks that formed part of the treatment plan: “... bringing him immediately to the baths and pouring a lot of tepid oil over him and rubbing him very gently, we ordered him to spend as much time in as possible in the water of the hot bath". ${ }^{[15]}$ It is known with some certainty that a number of nursing historians are correct in their observations that the role of the woman in providing nursing care was extremely limited, so much so that their 'nursing' activities were confined to the home in the form of wetnurses or providing care for the sick household slaves, as mentioned previously. This invariably meant the assistants that undertook the caring work, even at this time, were always undertaken by men. ${ }^{[5,14,16]}$ Yet, closer examination of the medical role (Iatroi) when caring for the sick shows some distinct similarities between what was deemed medical care and what we would call modern 'nursing care':

"... you must practice these things with all the reserve, in the matter of palpation, anointing, washing, to ensure elegance in moving the hands, in the matter of lint, compresses, bandages, ventilation and purges." (King, 1991; $14)^{[17]}$

Like the Carakasamhita, ${ }^{[18]}$ the embodiment of the physician/nurse was one of good character and aptitude to impress upon the patient and the household the virtues and technical prowess of the attending physician so that adulation and glory would be heaped upon them when the patient recovered. For example, King $(1991 ; 14)^{[17]}$ suggests that for the attendant to:

“... bear in mind your manner of sitting, reserve, arrangement of dress, decisive utterances, brevity of speech, composure, bedside manner, care, replies to objections, calm self-control to meet the troubles that occur, rebuke of dis- turbance [and] readiness to do what has to be done..."

Madeth the man. Of course King (1991 ${ }^{[17]}$ is right in her reappraisal of what was deemed nursing in ancient Greece was not as well developed as one would think, but then nor was medicine. However, one fact does remain, despite the rhetoric surrounding healing and healers of this time, it was always men who provided this care; limited though they were women looked after women within the confines of the home. ${ }^{[16]}$

Yet, one of the most important considerations in the development of nursing during this time period was seen largely in the military. It is well known that unlike Grecian healthcare, Roman healthcare showed little humanity for the individual person and combined with their public neglect of the sick ${ }^{[16]}$ meant these individuals were often left in the street to be offered assistance by any passer-by that showed compassion and a willingness to offer assistance. However, it was the military, the great Roman legions that promoted the role of the nurse. Known as nosocomi, the military nurse (male) attended to Roman legionnaires wounded in battle. This was often done in private dwellings, make shift tents or buildings, but it wasn't until the development of valetudinarium, purpose built military hospitals, that the Nosocomi came into fruition ${ }^{[2]}$ and largely as a result of Roman expansion during this time. Little is known what the Nosocomi did in terms of providing actual 'nursing' care as there was often an overlap between the Medici (physicians) and role of the Nosocomi and this is often down to modern interpretation of the terms used to denote medical/nursing care of the time. However, it is known that battle wounds accounted for less than $2.6 \%$ of all deaths, with the majority of illness and sickness down to the less than sanitary conditions the occupying army had to contend with - typhus, malaria, cholera and the plague. ${ }^{[19]}$ Therefore the challenge for the Nosocomi was more in line with maintaining the health of the army through the development and maintenance of clean drinking water systems, proper flushable latrines and bathhouses ${ }^{[19]}$ similar in many respects to Nightingale's work in the Crimea and India .

\section{The Christian ERA (1-400AD)}

Despite the emergence of Christianity as a religion, male only gods and deities still played a major role in the way healthcare was delivered especially so in Graeco-Roman mythology. Asklepios the Greek god of healing, the son of the god Apollo and a mortal woman Coronis was celebrated in numerous temples across the Roman Empire. ${ }^{[20]}$ His temples were often built on sites that not only offered views of natural beauty but were often chosen for their medicinal 
properties such as natural spring waters or refreshing breezes. Yet the process of healing was little more than esoteric in its function. For example patients admitted to the temple were put through a purifying process which included abstinence from certain foods and wine, were bathed and underwent elaborate religious rituals which culminated in them being granted the privilege of sleeping within sight of an Asklepian statue. It was through this 'temple sleep' that treatment for whatever ailment beset the patient would be revealed in a dream or hypnotic state. ${ }^{5]}$ It is evident that the cult like status of Asklepian healing provided a blend of natural and supernatural remedies, but in doing so allowed lay healers as well as nursing to develop their practice from a more empirical and practiced standpoint. ${ }^{[21]}$ However, there was a division with regard to healing practices: exorcism versus therapy ${ }^{[22]}$ as the Asklepian priests branched out into two distinct specialties - healing and the occult. ${ }^{[5]}$ The exorcist for example was granted the privileges bestowed upon the priests whose major role was the magical prevention of attacks from demons, angry gods and witches; whereas the healer was little more than an apothecary. ${ }^{[22]}$

What is perhaps noteworthy in the first 150 years of the Christian era was the slow decline in medical science. Romans were not noted for their medical originality. Much of what was considered health care during the Roman era was acquired from Grecian science and technology. ${ }^{[21]}$ Probably the most dominate figure during this time was the Geek physician Galen, who by all accounts lacked any real knowledge about medicine in general, yet set the precedent for all things medical so much so his medical compendium lasted well over 1,000 years. ${ }^{[23]}$ However, the Christian church continued to build 'hospital after hospital' in an attempt to meet the needs of the poor - these were little more than poorhouses as opposed to anything even remotely resembling a hospital. With it unfortunately began the demise of medicine, which meant that it became the domain of the priest to provide lay medical and nursing care. ${ }^{[21]}$ After the death of Marcus Aurelius in 180AD the Roman Empire fell into turmoil as did the provision of medical and nursing care. The time of idleness, extravagance and luxury was at an end ${ }^{[5]}$ and with it the relocation of the Mediterranean seat of power and influence to Constantinople in 330AD meant that healing/medicine/nursing grew exponentially. Influenced largely by the work of Galen and Christian ideology Byzantium became the birth place of 'real hospitals' ${ }^{[24]}$ despite evidence suggesting that hospitals were in existence in both Rome (Valetudinaria) and India many centuries before. In many cases these were predominately for the military (Roman) and hospices to aid the sick traveller (India).

It was the during the early Byzantine Empire that saw Con- stantine the Great (330AD) formally develop hospital based care, in which men were dominant in advancing organised nursing practice. ${ }^{[25]}$ Two of the more well-known hospitals, the Xenon of Pantokrator and the Xenon of Libs practiced according to the Christian ethos of altruism and philanthropy, one which saw care based upon the teachings of Christ and in particular the Corporal Work of Mercy: ${ }^{[5]}$ "To feed the hungry; to give water to the thirsty; to clothe the naked; to visit the imprisoned; to shelter the homeless; to care for the sick; [and] to bury the dead." All of which was seen as a means of storing up credit in the kingdom of heaven. It has to be remembered that in Byzantium hospitals nursing care was delivered through monastic institutions that provided care to the sick, poor and infirm and while conditions were suitable for the times the function of the hospital:

“... was [as] an ecclesiastical, not a medical institution. It was for care rather than cure; for the relief of the body, when possible, but preeminently for the refreshment of the soul... faith and love were more predominant features in hospital life then were [nursing] skill and science." $[26]$

As for the provision of nursing care; it was often gender specific where women provided care for women, mainly in providing solace, food and cleanliness (Diakonisses) or wet-nurse roles, whereas overall hospital administration and patient care was delivered predominately by men. ${ }^{[27]}$ More importantly, nursing was viewed as a sacred calling; an expectation that patients were viewed in the image of God himself (Christ's parable of the good Samaritan) and this could not be more extant than in the philosophy of nursing care which can be exemplified in the writings of Theodorus Studiae's 17th iambus "To the Nurse":

"It is a sacred thing to bear the load of the sick. Since you are honoured with this sacred privilege, my son, do struggle warmly and eagerly in the accomplishment of your duty. Early in the morning, first, visit and care for your bedridden patients, heat them mainly by your words, later serve them their appropriate diet in good manner and kind talking. Don't neglect the patient, because he is a member of Christ. If you care for your patient with zest and promptitude, you will be greatly rewarded by receiving the divine light, and heaven's in" (Kourkouta, et al., 2012; $176)^{[28]}$

In addition to the gender divide there was a financial gulf between the trained or ordained (Hypogouri) and the untrained

ISSN 1925-4040 E-ISSN 1925-4059 
nurse (Nosocomi) - nursing even at this time was seen as a very low occupation socially. Yet despite this, the nurse was responsible for ensuring that: "He looked after the need of the patients; he supervised the provision of good medical and nursing care; he ensured the patients were well fed as possible; he was responsible for the hospitals supplies - provisions and medicines; [and] he exercised discipline over the other staff and patients." (Kourkouta, 1996; 51). ${ }^{[29]}$

Certainly the Council of Nicaea in 325AD decreed that each bishop was to establish their own hospital (Xenodocheion) as an economical means of gathering all the 'unfortunates' into one institution. ${ }^{[21]}$ During the same period, the Parabolani, a sect of Christian fundamentalists based in Alexandria, started a hospital that provided nursing care during the great plague of 252AD. Originally conceived in the early 3rd century AD, the Parabolani were seen as a group of specialised persons necessary to care for the sick and dispose of the dead from hospitals. For example, Parabolani grave diggers (copiatae) of the time were typically seen as workers to be kept outside of the city gates naturally because of the work they undertook. ${ }^{[30]}$ The Parabolani, meaning "reckless ones", often volunteered to search for plague victims to bring to hospital for treatment in addition to burying the dead which often meant risking their own lives in the process. ${ }^{[31]}$ However, they were also notorious for their violence and brutality and often at the behest of the Bishops with to whom they were responsible; Bishop Cyril being the more noted member of the clergy in Alexandria. This notoriety often overshadowed the caring work that they have been noted for and certainly calls into question their caring ethos against a back-drop of thuggery and murder. Nevertheless, Kingsley $(1907 ; 80)^{[32]}$ in providing a descriptive account of their 'nursing work provides some insight to the often perilous and dangerous work the Parabolani undertook, for example:

"... carrying food and clothing, helping the sick to the hospital, and dead to the burial; cleaning out the infected houses - for the fever was all but perennial in those quarters - and comforting the dying with the good news of forgiveness from above."

The eventual fall of Rome in 476AD precipitated the 'Dark Ages', a European technological stagnation which saw Christian monastic influences promulgating the hospital and nursing movement. ${ }^{[33]}$

\section{The Middle Ages: THE BIRTh of ME- DIEVAL NURSING (500-1500AD)}

With the decline in medical technology the provision of care to the sick, infirm and elderly fell more to the responsibility of the religious orders. By the 6th century many western churches had purpose built hospitals that provided nursing care to the local populace. This care might simply encompass 'a nights board and lodging' or the seeking of solace from a healing shrine. ${ }^{[21]}$ Medicine was seen as little more than faith healing at best, and for the majority of the population medical therapy was loosely based on self-treatment, or that provided by lay-people. ${ }^{[3]}$ For example a famous surgeon of the time remarked when asked to explain the cause of the black plague blamed it on the alignment of Saturn, Jupiter and Mars in the sign of Aquarius as opposed to contagion theory - the spread of bacteria infested fleas and rats. ${ }^{[21]}$ Actual patient care was often delivered by the monks or nuns but more commonly by religious servants assigned to care for the ill. Yet it was the promise of eternal salivation that drove the religious to view their main duty as to provide care for the sick. - "he that hath mercy on the poor lendeth to the Lord and he will repay him". [34] More notable figures such as St Francis of Assisi, so appalled by the treatment and suffering of lepers, gave up his ministry to provide care for these individuals. Others such as the Franciscan friars and the Order of the Holy Ghost (Santos Spirito) devoted themselves to the nursing care of those individuals who required it. Yet it was in the Byzantium hospitals of the medieval period that saw a rise in the status of nursing. Because of the substantive growth in Byzantine cities, nursing evolved into a specialist occupation in its own right, more so than it did in the west during the same period. The traditional volunteer caregiver from within the religious orders was now being replaced by paid nursing assistants who were contrary to belief men. ${ }^{[3]}$ While it is fair to say that women were also active in providing nursing care, the continuing might of the male dominated church imposed almost impossible conditions on the convents, so much so that they were to eventually become cloistered behind closed doors; their work for the sick and needy was confined solely to the sisters. ${ }^{[21]}$

\section{The Warrior Monks: Nurses Extraordinaire}

Perhaps the most extraordinary nurses of the medieval period were those established by the military religious brotherhood. It was believed that the coming millennium (1000AD) would bring the world as it was to an end. As a result a large number of Christian pilgrims made the arduous journey to the holy land in search of penance. The growing number of pilgrims brought with it an increase in the incidences of violence perpetrated upon them mainly by Moslem cabals. The ill-treatment they received motivated wealthy Amalfian merchants to establish two hospitals in Jerusalem to bring aid and comfort to the growing pilgrim numbers ${ }^{[35]}$ The rising religious fervour across Europe and the Middle East at this time prompted Pope Urban II at the Council of Clermont 
to call upon the Christian west to take up arms to rid the

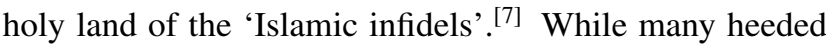
his call, it was the first crusade of 1095AD that heralded the rise of the militaristic religious nursing orders, such as the Knights Hospitallers, the Knights Templar and the Teutonic Knights. Building a number of hospitals throughout the holy land, these religious orders provided nursing care not only to Christians but to Muslim soldiers and citizens as well. Such was the quality of care, never before seen in any other hospitals of the time, patients were provided with a lavishness that was only ever reserved for the very wealthy. Before being admitted into the hospital the sick were bathed before being carried to a bed:

"Each bed had its own coverlet and sheet... each ward had nine sergeants who washed the feet of the sick, changed their linen, made the beds, fed the weak and in general took care of the sick." (Bullough \& Bullough, 1993; 96). ${ }^{[3]}$

Canon law at the time stipulated that despite being religious orders the care of the sick came first and foremost. Fighting by day and tending the wounded and sick by night, these warrior nurses faithfully attended the sick and infirm with a watchfulness, care and patience because the reward was undoubtedly heavenly salvation.

\section{The Reformation and the Renais- SANCE (1500-1700AD)}

During the early renaissance the extension of commerce and the development of the fine arts saw a revival in the bourgeoisie and the landed gentry in which trade and industry flourished. But more importantly it saw a rise in the development of the practical arts - ship building, glass-working and metal craft for example. Perhaps one of the greatest inventions of the period was the printing press which meant that medical texts were now readily available and with it came the study of 'natural philosophy' - the natural sciences of physics, biology and of course medicine. While medicine was slowly seen as becoming a science in its own right, physicians were often opposed by the ecclesiastical authorities who up until this time were responsible for the care of the sick. ${ }^{[21]}$ However, the church was not entirely opposed to the development of science, what it disagreed with was sciences interference and conflict with theology. Of course there was an element of 'quackery' as medicine developed because as is often the case the nature of 'nature' remained inexplicable and therefore medicine and magic remained almost synonymous with each other. It wasn't till the mid-16th century that Vesalius wrote Fabrica (the fabric of the human body) that a better understanding of human anatomy emerged, some suggesting that it completely corrected and re-envisaged the work of Galen. ${ }^{[36]}$ What followed was a rudimentary understanding of pathology (1679AD) and disease transmission (1660AD).

Despite the emergence and development of medicine as a science, this period is often viewed by many nursing historians as 'nursing's dark age' (1600-1850). The deplorable conditions of hospitals was seen as a failing of medicine in not being able to improve medical practice but then neither had nursing progressed. The rise of secularism meant that the popularity of the church was beginning to wane and with it the rise in individual material and financial wealth. This often led to hospital administrators embezzling hospital funds for their own personal needs. As a result hospitals fell into disrepair, equipment and goods were sold to line the coffers of the less scrupulous all the while men and women were dying in great misery. Yet it was the reformation that saw the demise of nursing, primarily through the protestant reforms; ${ }^{[37]}$ the main instigator being Henry VIII in his quest to divorce Catherine of Aragon. Suppressing the Catholic Church and confiscating property from 600 charitable endowments, Henry VIII had very nearly, single handily brought nursing to the brink of extinction in England. ${ }^{[21]}$

For many years, hospital based nursing was staffed largely by the catholic religious orders. As Protestantism firmly took hold in northern Europe, monks and nuns were driven underground taking with them their expert nursing knowledge, skills and literature. ${ }^{[2]}$ The Elizabethan 'Poor Law in 1601' was enacted to enable the sick and infirm to be cared for in almshouses which in turn were funded by government taxation. While publicly funded charitable health care was seen as a new panacea, the hospitals charged with this care were often viewed as wholly inefficient and ineffectual the church based organisations were seen as the pinnacle of health care delivery and why shouldn't they; they had been doing it far longer. As a result hospitals resorted to employing secular organisations that often lacked the discipline to run and manage these effectively, and frequently employed nurses with questionable skills and of dubious character. The male nursing figure was beginning to give way to their female counterparts, largely because of feudal warring and political infighting. Medicine at this time sought refuge in the universities and as a result was allowed to thrive and prosper. With the lack of structure and organisation hospitals become places of horror; unsanitary conditions, substandard care and cruelty, many patients were starved or simply died of maltreatment, in some cases fatally overdosed because of the illiteracy of the nurses caring for them. ${ }^{[31]}$ Women of low repute were often forced to undertake nursing duties in lieu of serving jail sentences; for many nurses prostitution 
was seen as a more favourable occupation - nurses were the lowest of the low. ${ }^{[38]}$ The male nurse had almost disappeared except for the mental asylums where their physical strength was considered a blessing in handling the violent mentally ill $^{[39]}$ and the military.

\section{1800AD - FLORENCE Nightingale}

Up until 1851, the year Florence Nightingale first went to Kaiserswerth, nursing was seen as not the most desirable of professions. It was viewed primarily as a line of work that helped individuals escape the horrors of the prison system; only prostitution and domestic servitude were considered better alternatives. The period between 1820 and 1850, saw nursing as an undisciplined, raucous, uncouth rabble that appeared to be a law unto themselves so much so that one might be reminded of images of Sarah Gamp and Betsy Prig prominent figures in Dickens' Martin Chuzzlewit. ${ }^{[40,41]}$ Despite the best efforts of a succession of Matrons, nurses under their control flouted the rules and consistently put the lives of patients at risk, through drunkenness, petty pilfering of drugs and medicines especially stimulants and at times refusing to provide any form of nursing care. ${ }^{[41]}$ After 1840 , the establishment of nursing sisterhoods saw religious sectarianism begin to take control of the profession and attempt to bring some dignity to the pervading image that the 'gindrinking' nurse of this era portrayed. ${ }^{[42]}$ It was also at this time (1851) that Nightingale went to Kaiserswerth, attracted by the opportunity of training to be a nurse, her life-long passion, in an institution that had no equal anywhere in the western world. ${ }^{[43]}$

It is without a doubt that Florence Nightingale transformed nursing and this could not be more evident in her early endeavours at Scutari during the Crimean War (1853-1856). Requested by the then Secretary of War, Sydney Herbert, Nightingale with a small group of nurses travelled to Turkey to provide nursing services to the sick and wounded soldiers. ${ }^{[21]}$ With Britain's entry into the Crimean War the mortality rate for wounded soldiers stood at approximately $42 \%$. After a highly publicised campaign to provide competent and expert nursing and medical care, Nightingale excelled in bring nursing to the forefront of public opinion. It is readily and widely accepted that she is seen as the most iconic, quasimythic feminist figure which embodied the ideal of nursing and what's more it was the Crimean war that catapulted her to 'nursing stardom'. ${ }^{[42,44]}$ Her fastidiousness towards cleanliness, hygiene and sanitation reduced the soldiers' mortality rate to approximately $2 \% .^{[5]}$ On her return from the Crimea, Nightingale set about developing a training school for nurses at St Thomas' Hospital London with a $£ 50,000$ dowry she received from the Government and through public donations; this became known as the Nightingale Fund.

On her return to England, back from travels in Turkey, the Crimea and India, Nightingale was uninspired with the unproductive life of the Victorian women. In her teens a religious divination persuaded her that nursing may be the 'out' that she needed to be able to direct her energies as opposed to conforming to ${ }^{[45]}$ Stark's $(1979 ; 4)$ representation of the 19th century woman:

\begin{abstract}
"Victorian England was a country in the grip of an ideology that worshipped the woman in the home. Women were viewed as wives and mothers, as potential wives and mothers and failed wives and mothers. The woman who was neither wife nor mother was called the 'odd woman' or the 'redundant women'. Woman was at the centre of the age's cult of the family, 'the angel in the house', tending the domestic altar. She was viewed as man's inferior - less rational, weaker, needing his protection; but at the same time, she was exalted for her spirituality, her moral influence."
\end{abstract}

Yet, the idea of nursing as a role for women in Victorian society was not necessarily reticent of public opinion at the time. Indeed the interest in nursing was less about gender based employment as it was about the importance of public health and sanitation. Moreover, in 1848 it was mooted that an institute for the training of hospital based nurses be established, not so much about careers for women but more about developing and training a specialised workforce for the nation's hospitals ${ }^{[42]}$ which at this time were no better than establishments of unmentionable horror ${ }^{[21]}$ or simply places to go and die. ${ }^{[41]}$ Yet by the 1870's the feminisation of nursing was well established. Beale $(1873 ; 630)^{[46]}$ in a lecture to medical students, wryly commented that:

"Nursing is especially women's work... it is work that requires care and intelligence, to which the most clever women might devote herself without feeling that she was fitted for and ought to have been engaged in prosecuting work of a high kind. Higher or better work there cannot be."

However, of note is that much of what is written about nursing during the early to mid-19th century is from the basis that women were the predominate nursing figure in the public hospital system. Yet, what is often forgotten is that male nurses were in abundance not only in supporting wounded soldiers at Scutari and other various field hospitals throughout the 
Crimean campaign, but there were already a significant number of male nurses already working in the hospital system. Records from the time suggest that male nurses accounted for $27 \%$ of the nursing workforce. Indeed, the Times newspaper of 1876, reported:

“... a very few men are naturally disposed to nursing. They are sympathetic and gentle; they have no excessive flow of spirit or range of ideas; they can speak when spoken to, and hold their tongue when it is fit to be silent. They attend to small matters and bear them in mind. They can take pleasure in small arrangements, so as they have a use or propriety. They can attach significance to such superficial matter as dirt or smell. They can believe in orders which they cannot themselves understand. They can mediate between the doctor and the patients, being a faithful assistant to the former and a kind but not oppressive, friend and advisor to the latter." (The Times, 1879; 7) ${ }^{[47]}$

This could not be more evident than in the comments of prominent physician Sir William Gull where he has been quoted as saying that it is "poetical fiction to suppose that women have an inherent fitness for nursing" (cited, Young, 2008; 20). ${ }^{[42]}$ However, it was the military and the mental asylums that the male nurse gained prominence. ${ }^{[39]}$ This was different of course for hospital based nursing in which by 1885 , hospitals were totally staffed by female nurses. ${ }^{[42]}$ Not to be deterred, the philanthropist Jane Hamilton established in 1885 the Hamilton Association for the Training of Male Nurses; a much welcomed positive innovation by a number of leading physicians, who at the time found it difficult to find suitably skilled nurses to provide expert care to their numerous cases. ${ }^{[48]}$ Seen as the pinnacle of male nurse training, the Association became the foremost supplier to the Army Medical Staff Corp simply because male nurses made 'superior nurses to their female counterparts' [sic]. Of course, the intention of the association was not to displace their female counterparts, but to supplement the nursing ranks with others "that illness often necessitates great strength to meet the requirements of bedridden men, and that in various surgical operations and other circumstances a male nurse is of the utmost service". ${ }^{48]}$

As the 19th century grew to a close, the needs for the male nurse started to decline. Junior medical officers, known as dressers, were doing more of the nursing work that might otherwise be attributed to both female and male nurses. ${ }^{[38]}$ Men were employed as orderlies or attendants, in some cases as a result of financial hardship, to provide rudimentary care when called upon especially in instances where is deemed inappropriate or unsuitable for female nurses to provide that level of care. ${ }^{[49]}$ Other factors such as the severe losses of men during the Crimean War, the continued development of the industrial age, the continued lowly status of nursing and the declining number of men in the profession allowed women to develop dominance within the profession.

\section{Conclusion}

Against this varied historical background, it would be remiss to suggest that men have paved the way for nursing as it is today. Instead men's contribution to nursing has, for the most part, been integral in helping to establish nursing in its own right. It was Florence Nightingale that reformed nursing into the female dominion that the profession is today ${ }^{[2]}$ and in some respects it was Florence Nightingale that may have finally put paid to the image of the male nurse, ${ }^{[1]}$ though not through any malicious intent. However she is not solely responsible for their demise, but rather she was integral in trying to establish careers for women (Christman, 1988) and it is unfortunate that the male nurse was often seen as counter to this ideal.

Yet despite this the 'male nurse' is ever present in most aspects of nursing and while many would simply like to refer themselves as nurses, the number of men who are registered is slowly increasing, not in large numbers but increasing none the less; men are becoming an accepted member of the health care environment and prominent male nursing leaders such as Luther Christman, were paving the way for future generations of male nurses.

\section{Conflicts of Interest Disclosure}

The author declares that there is no conflict of interest.

\section{REFERENCES}

[1] Evans J. Men nurses: a historical and feminist perspective. Journal of Advanced Nursing. 2004; 47(3): 321-328. PMid:15238127 https://doi.org/10.1111/j.1365-2648.2004.03096.x

[2] O'Lynn CE. History of men in nursing: a review. In: O'Lynn C.E.,
Tranbarger, R.E., Men in Nursing: History, Challenges and Opportunities. Springer, New York; 2007. PMid:17998853

[3] Bullough VL, Bullough B. Medieval Nursing. Nursing History Review. 1993; 1(1): 89-104. PMid:8453408

[4] Mackintosh C. A historical study of men in nursing. Journal of Ad- 
vanced Nursing. 1997; 26(2): 22-236. https://doi.org/10.104 6/j.1365-2648.1997.1997026232.x

[5] Donahue P. Nursing: the finest art, 3rd edition. Mosby, St Louis. 2010.

[6] Green MH. Documenting medieval women's medical practice. Women's healthcare in the Medieval West. Aldershot, Ashgate Variorum. 2000. 322-352.

[7] Nutting MA, Dock LL. A history of nursing: the evolution of nursing systems from the earliest times to the foundations of the first English and American training schools for nurses, Vol 1. G.P.Putnams Sons, New York; 1937.

[8] Ghai S, Ghai CM. The ancient origin of nursing in India. The Nursing Journal of India. 1997; 88(6): 131-132. PMid:9384196

[9] Zucconi LM. Medicine and religion in ancient Egypt. Religion Compass. 2007; 1(1): 26-37. https ://doi .org/10.1111/j.1749-8 $171.2006 .00004 . \mathrm{x}$

[10] Saber A. Ancient Egyptian surgical heritage. Journal of Investigative Surgery. 2010; 23(6): 327-334. PMid:21208098 https: //doi.org/10.3109/08941939.2010.515289

[11] Rosalie D. The art of medicine: the art of healing in Ancient Egypt a scientific reappraisal. The Lancet. 2008; 273(9652): 1802-1803.

[12] Caton R. Two lectures on the temples and ritual of Asklepios at Epidaurus and Athens. The British Medical Journal. 1879; 1(1955): 1572-1575.

[13] Nutton V. Ancient Medicine. Routledge, London; 2004.

[14] Levine EB, Levine ME. Hippocrates, father of nursing, too? American Journal of Nursing. 1965; 65(12): 86-88. PMid:5319739

[15] Mattern SP. Galen and the rhetoric of healing. The John Hopkins University Press. Baltimore. 2008.

[16] Sharp EE. Nursing during the pre-christian era. The American Journal of Nursing. 1919; 19(9): 675-678.

[17] King H. Using the past: nursing and the medical profession in Ancient Greece. In: Holden, P., Littlewood, J. Anthropology and Nursing. Routledge, London. 1991.

[18] Leslie J, Wujastyk D. The doctor's assistant: nursing in Ancient Indian medical texts. Anthropology and Nursing. Routledge, London. 1991.

[19] Scheidel W. Marriage, Families and Survival: demographic aspects. In Erdkamp, P., (2007). A Companion to the Roman Army. Blackwell, London. 2007. PMid:17431627 https ://doi .org/10.100 2/9780470996577. ch24

[20] Abrahamsen V. The Goddess and Healing: Nursing's heritage from Antiquity. Journal of Holistic Nursing. 1997; 15(1): 924. PMid:9146192 https://doi.org/10.1177/089801019701 500103

[21] Shyrock RH. The history of nursing: an interpretation of the social and medical factors involved. Saunders, Philadelphia. 1959.

[22] Geller MJ. Ancient Babylonian Medicine: theory and practice. WileyBlackwell, Oxford. 2010. https://doi.org/10.1002/978144 4319996

[23] Temkin O. Byzantine medicine tradition and empiricism. Dumbarton Oaks Papers. 1962; 16(1): 95-115.

[24] Kourkouta L. Some details of the administration and functioning of the Byzantium hospitals. International History of Nursing Journal. 1997; 3(1): 79-85. PMid:11619707

[25] Miller RJ. Men in Nursing: a grounded theory study. Unpublished $\mathrm{PhD}$ Thesis, University of Idaho College of Graduate Studies. 2004.
[26] Seymer LR. A general history of nursing. London, Faber and Faber 1932.

[27] Kourkouta L. Working conditions and duties of nurses in Byzantium. International History of Nursing Journal. 1998; 4(1): 32-34. PMid:11623514

[28] Kourkouta L, Plati P, Ouzounakis P. The meaning of nursing in Byzantium. Progress in Health Science. 2012; 2(1): 175-178.

[29] Kourkouta L. Terms used in Byzantium for nursing personnel. International History of Nursing Journal. 1996; 2(1): 46-57. PMid:11613456

[30] Rebillard E. The care of the dead in late antiquity. New York, Cornell University Press. 2009.

[31] Klein JE. Lived experiences of men in nursing: chickadess, stepping stones and muddling through maternity. Unpublished $\mathrm{PhD}$ Thesis, University of North Dakota. 2009.

[32] Kingsley C. Hypatia. Everyman's Library, London. 1907. PMid:17833258

[33] Cilliers L, Retief FP. The evolution of the hospital from antiquity to the end of the middle ages. Curationis. 2002; 25(4): 60-66. PMid:14509111 https://doi.org/10.4102/curationis.v25 i4. 806

[34] Lorentzon M. Care of the sick in medieval London. History of Nursing Society Journal. 1992; 4(2): 100-110. PMid:11614022

[35] Barber M. The Crusader States. Yale University Press, London. 2012.

[36] Natale G, Lazzeri G, Guagnozzi M, et al. Vesalius 500 years later: the lesson of Fabrica. Itilian Journal of Anatomy and Embryology. 2014; 119(1): 138.

[37] Mericle BP. The male as psychiatric nurse. Journal of Psychoscoial \& Mental Health Services. 1983; 21(11): 28-34.

[38] Abel-Smith B. A History of the Nursing Profession. Hienemann, London. 1960. PMid:13791441

[39] Boschma G. The gender specific role of male nurse in Dutch Asylums: 1890-1910. International History of Nursing Journal. 1999; 4(3): 13-19. PMid:11623866

[40] Summers A. The mysterious demise of Sarah Gamp: the domiciliary nurse and her detractors, c.1830-1860. Victorian Studies. 1989; 32(3): 365-386.

[41] Helmstadter C, Godden J. Nursing before Nightingale: 1815-1899. Farnham, Ashgate. 2011.

[42] Young A. Entirely a woman's question? Gender and the Victorian nurse. Journal of Victorian Culture. 2008; 13(1): 18-41. https://doi .org/10.3366/E1355550208000052

[43] Seymer L. Florence Nightingale at Kasierswerth. American Journal of Nursing. 1951; 51(7): 424-426. PMid:14857019

[44] Gamarnikow E. Nurse or women: gender and professionalism in reformed nursing 1860-1923. In: Holden, P., Littlewood, J., (1991). Anthropology and Nursing. Routledge, London. 1991.

[45] Stark M. Introduction to Cassandra: an essay by Florence Nightingale. Old Westbury, New York Feminist Press. 1979.

[46] Beale LS. Lecture on hospital patients, doctors and nurses. The Medical Times and Gazette: Journal of Medical Science. Vol 2, December 6th; 1873; 630-632.

[47] The Leader. The Times 14 April 1876: 7.

[48] Prosser J. Men as nurses. The Westminster Review. 1897; 147: 309310.

[49] Painton JF. The outlook for male nursing. The American Journal of Nursing. 1937; 37(3): 281-282. 